\title{
A personal tribute: Iain D. Campbell FRS (1941-2014)
}

This is not an obituary for Professor Iain Campbell FRS (1941-2014) who passed away on 5th March 2014, but rather a personal tribute to a remarkable scientist who published his final review article in this journal [1]. Iain's commitment to scientific research and academic life at Oxford University, where he was employed for over four decades, is exemplified by the fact he continued to be active until few weeks before his death. When I contacted Iain in May 2013, requesting him to write an article on the developments in protein NMR spectroscopy, his response was as follows:

"Sounds as if you want an old man's overview and historical perspective! I will have a go, aiming for 5 printed pages."

Despite being diagnosed with cancer he went onto produce an article entitled "The evolution of protein $N M R$ " [1], which to my delight was much longer than the 5 pages he originally suggested. This was typical of the man who vigorously engaged in scientific and academic activities right up to the end (see Fig. 1).

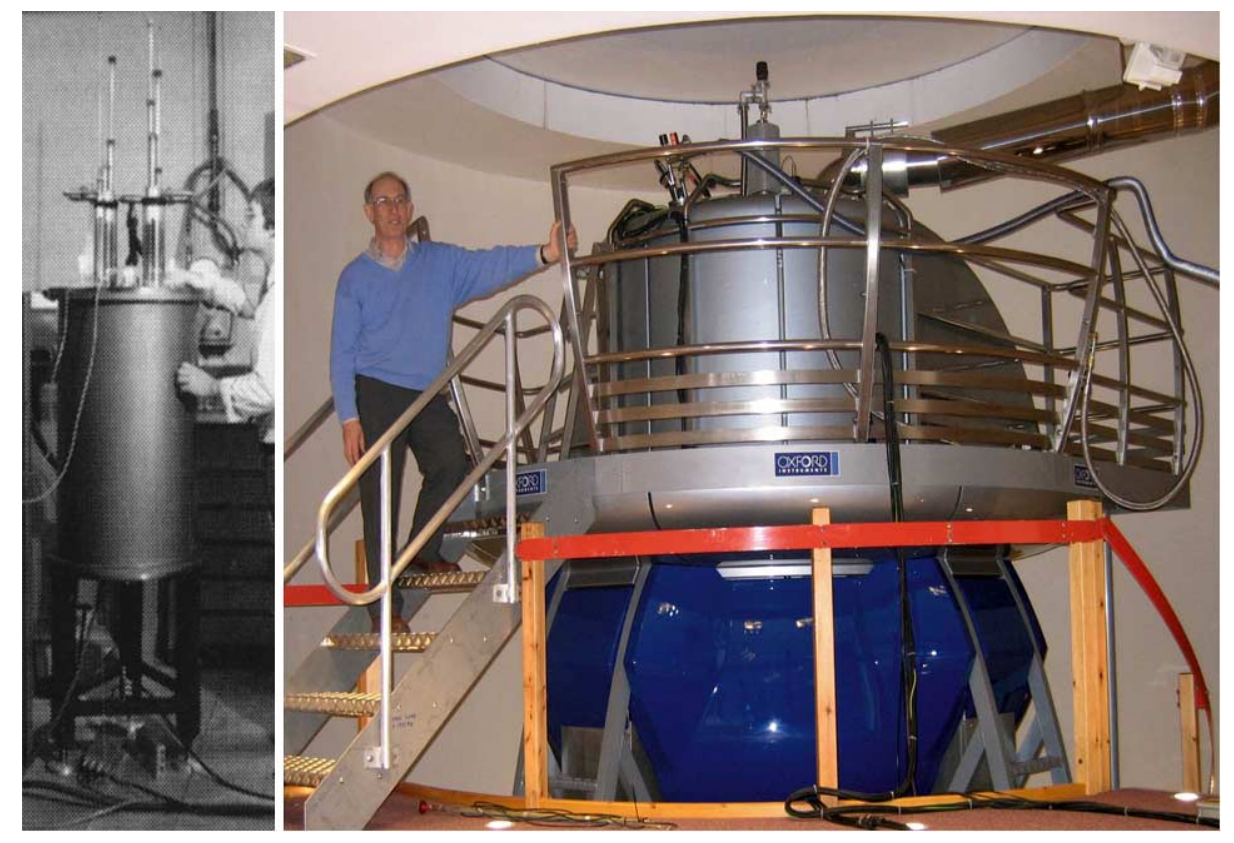

Fig. 1. Reproduced from P.I. Haris, 2013 [2]. Left: Picture of the early $270 \mathrm{MHz}$ NMR spectrometer that Iain Campbell used at Oxford (photograph taken in 1971). Right: Iain standing next to a $950 \mathrm{MHz}$ NMR spectrometer at Oxford (photograph taken in ca. 2008). (Colors are visible in the online version of the article; http://dx.doi.org/10.3233/BSI-140088.) 
The last message I received from Iain was on the 7th of February 2014. This was after he returned home from hospital. He wrote the following regarding the publication of his review article in Biomedical Spectroscopy and Imaging:

"Thanks for asking me to write the article, it was a timely opportunity for me and I enjoyed doing it."

It gives me great comfort that Iain not only appreciated my request but he also enjoyed writing this article particularly during a period when he was unwell. It was not an ordinary review but one where he expressed his personal opinions regarding how protein NMR spectroscopy developed and his predictions about the future of this important and growing field of research. This article can serve as an important historical document since, to the best of my knowledge, it was the final review article Iain published before his death. It contains some thought provoking statements from one of the pioneering NMR spectroscopists. I produced an editorial in this journal, to accompany his article, where I called him a "revolutionary spectroscopist" [2] since he made some key advances in the application of NMR spectroscopy for protein structural analysis.

With the departure of Iain Campbell, the scientific community has lost one of the brilliant spectroscopists of recent times. This loss has been particularly felt in the United Kingdom where he was highly admired by his colleagues, peers and students. Several different obituaries have been published in national newspapers and scientific journals such as Nature Structural \& Molecular Biology [4] and Structure [5]. One of the best obituaries has been produced by his colleague, Professor Mark Sansom, who is currently the Head of Biochemistry Department at Oxford University [5]. I have collaborated with Mark [3] and I was aware of his links with Iain. Mark knew Iain for far longer than I did and therefore it would be appropriate to reproduce the following paragraph from his article [5]:

"How should we remember Iain? First and foremost, as a rigorous, enthusiastic, and inspiring researcher. At a personal level, he was a wonderful colleague to work with. I failed to join Iain's research group as an undergraduate, but 30 years later I had the privilege to collaborate with him on the interactions of the talin/integrin complex with lipid bilayers. I still recall emailing Iain a draft manuscript for his comments, thinking that I could then return to the task in a few days. Within the hour, Iain had returned the manuscript, fully commented and much improved (Kalli et al., 2010). This exemplified his focus and energy. We will miss him."

I fully agree with Mark, it truly reflects the character of a man who has inspired and influenced so many scientists around the world through his research and educational contributions. There is no doubt that the world has lost a great scientist and a teacher. However, his legacy will continue to influence and inspire a new generation of scientists thanks to the many scientific contributions he has left behind.

Parvez I. Haris

De Montfort University Leicester, United Kingdom

\section{References}

[1] I.D. Campbell, The evolution of protein NMR, Biomedical Spectroscopy and Imaging 2 (2013), 245-264.

[2] P.I. Haris, Iain D. Campbell - A revolutionary NMR spectroscopist, Biomedical Spectroscopy and Imaging 2 (2013), 241243.

[3] P.I. Haris, B. Ramesh, M.S. Sansom, I.D. Kerr, K.S. Srai and D. Chapman, Studies of the pore-forming domain of a voltage-gated potassium channel protein, Protein Engineering 7 (1994), 255-262.

[4] C. Redfield, Iain D. Campbell 1941-2014, Nature Structural \& Molecular Biology 21 (2014), 427-428.

[5] M.S.P. Sansom, Iain Campbell - A personal recollection, Structure 22 (2014), 507-508. 